\title{
Validation of Immunoassay Methods to Determine Hydrocarbon Contamination in Estuarine Sediments
}

\author{
Gilberto Fillmann, ${ }^{*, a}$ Márcia C. Bicego, ${ }^{b}$ Ademilson Zamboni, ${ }^{a}$ Tim W. Fileman, ${ }^{d}$ \\ Michael H. Depledge and James W. Readman ${ }^{d}$ \\ ${ }^{a}$ Fundação Universidade Federal do Rio Grande, Departamento de Oceanografia, CP 474, \\ 96201-900 Rio Grande-RS, Brazil \\ ${ }^{b}$ Universidade de São Paulo, Instituto Oceanográfico, 05508-900 São Paulo-SP, Brazil \\ ${ }^{c}$ Plymouth Environmental Research Centre, University of Plymouth, Drake Circus, Plymouth, PLA 8AA, UK \\ ${ }^{d}$ Plymouth Marine Laboratory, Prospect Place, West Hoe, Plymouth, PL1 3DH, UK
}

\begin{abstract}
O desempenho de dois kits comerciais de ensaios imunológicos (ELISA com anticorpos ligados a partículas magnéticas) foi avaliado para a quantificação de hidrocarbonetos em sedimentos estuarinos. O kit BTEX RaPID Assay ${ }^{\circledR}$ foi utilizado para analisar hidrocarbonetos alifáticos e aromáticos leves, enquanto que o kit c-PAH RaPID Assay ${ }^{\circledR}$ foi utilizado para hidrocarbonetos poliaromáticos carcinogênicos ( $\geq 4$ anéis aromáticos). Os resultados foram validados comparando com análises feitas por cromatografia gasosa com detectores de ionização de chama (GC/DIC) e de espectrometria de massa (GC/EM). Foi observada uma boa correlação entre as técnicas $\left(r^{2}=0,68-0,97\right)$, estando a disparidade relacionada a diferenças na composição relativa de hidrocarbonetos que afeta a resposta dos anticorpos dos testes ELISA. De uma forma geral, os resultados obtidos com os kits ELISA foram comparáveis aos obtidos por cromatografia, confirmando a validade dessa técnica em protocolos de avaliação preliminar, visando o emprego de técnicas analíticas de alta resolução em amostras específicas.
\end{abstract}

The performance of two commercially available enzyme-linked immunosorbent assay (ELISA) kits (with antibodies attached to magnetic particles) for quantification of hydrocarbons in estuarine sediments is described. The BTEX RaPID Assay ${ }^{\circledR}$ was employed to analyse aliphatic and small aromatic hydrocarbons whilst the c-PAH RaPID Assay ${ }^{\circledR}$ was used to analyse the carcinogenic ( $\geq 4$ aromatic rings) polycyclic aromatic hydrocarbons. Results were validated by comparison with analyses by gas chromatography (GC)- Flame Ionisation Detection (FID) (with GC-MS confirmation). Correlations between the techniques were good with $\mathrm{r}^{2}$ values ranging between 0.68 and 0.97 . Disparity between immunoassay and GC techniques were related to differences in the relative compositions of the complex mixtures of hydrocarbons, which alter ELISA responses. Overall, results from the ELISA techniques are shown to compare well with those obtained by GC, confirming ELISA as a useful screening protocol to focus use of the more expensive and time consuming high resolution analytical techniques.

Keywords: immunoassay, ELISA, hydrocarbons, PAHs, validation, sediment

\section{Introduction}

Aliphatic and aromatic hydrocarbons are amongst the most commonly detected contaminants in the aquatic environment, deriving from petroleum and combustion processes. Their ubiquity and frequently high concentrations creates environmental concern regarding

*e-mail: gilberto@pq.cnpq.br ecotoxicological effects. Although a wealth of literature addresses these as important environmental pollutants, there is a weak link between chemical investigations and biological effect assessments using ecotoxicological methods. Often, time consuming chemical methods do not provide the response needed for rapid environmental assessments. However, immunoassay techniques have been directed towards measuring environmental contaminants. ${ }^{1-10}$ The most common format used for 
environmental analyses is the ELISA (enzyme-linked immunosorbent assay). ${ }^{1,11}$ This has proven to be rapid and cost effective $6,12,13$ and can usefully complement ecotoxicological methods in environmental assessments. ${ }^{14}$

Immunoassay-based analytical methods are rapidly gaining acceptance. However, it is necessary for any new analytical method to be rigorously validated before it can considered as a replacement for, or adjunct to, currently used laboratory methods. In a review article the scarcity of available information on the "real" environmental applications of immunoassays were noted. ${ }^{1}$ Multiple and independent evaluations lend credibility to the method. Most currently available immunoassay validations have been produced by the kit manufacturers. ${ }^{2,4}$ Therefore, independent evaluations of these kits are necessary to enhance the acceptance of the technology by potential users. The use of commercial immunoassays for field-testing has been encouraged. ${ }^{15}$ In the present work, a laboratory study was conducted to evaluate the performance of two commercially available ELISA kits (BTEX and carcinogenic PAH RaPID Assays ${ }^{\circledR}$ ) for quantification of hydrocarbons in sediment samples using the protocol described by the manufacturer, since the great majority of users will apply the techniques as specified.

The BTEX RaPID Assays ${ }^{\circledR}$ was employed to analyse aliphatic and small aromatic hydrocarbons, while the cPAH RaPID Assays ${ }^{\circledR}$ was employed to analyse the polycyclic aromatic hydrocarbons ( $\geq 4$ aromatic rings). Thus an estimate of "total" hydrocarbon (from natural and/or anthropogenic sources) is obtained by screening measurements from both assays. Results were validated by comparison with gas chromatographic analyses (GCFID with GC-MS confirmation).

\section{Experimental}

\section{Materials}

A certified standard reference solution of 24 aromatic hydrocarbons (NIST-SRM 1491) and authentic standards of aliphatic hydrocarbon ( $n-\mathrm{C}_{12}-\mathrm{C}_{35}$, phytane and pristane) were purchased from Promochem (Herts, UK). Internal standards ( $\mathrm{C}_{18: 1}$ and 9,10-dihydroanthracene) were acquired from QMx Laboratories Ltd (Safron Walden, UK). Solvents of glass distilled grade were from Rathburns Chemicals Ltd (Walkerburn, UK). Solvents were batch tested for PCB and PAH contamination. Silica (70-230 mesh), alumina (70-230 mesh) and anhydrous sodium sulphate were purchased from BDH Merck LTD (Lutterworth, UK).

\section{Samples}

Fortified sediments, standard reference sediments and environmental sediment samples were analysed in order to assess the performance of the methods. Soxhlet extracted dry sediments (10 g) were fortified with either PAH (SRM 1491) or $n-\mathrm{C}_{12}-\mathrm{C}_{35}$ standard mixture solutions prepared in hexane to yield sediment concentrations from 41 to $1,650 \mathrm{ng} \mathrm{g}^{-1}$ or 14 to $112 \mu \mathrm{g} \mathrm{g}^{-1}$, respectively. Fortified sediment samples were left stabilising for $6 \mathrm{~h}$ before Soxhlet extraction. Five different standard reference sediments were selected including HS-4B and HS-5 (National Research Council of Canada), IAEA 383 (International Atomic Energy Agency-Marine Environment Laboratory, Monaco), and QPH 16MS and QPH 17MS (Quasimeme Laboratory Performance Studies Round 12, UK). The environmental samples used included 16 sediments from the Patos Lagoon estuary (southern Brazil). Samples were collected in December 1999 and maintained frozen until analysis.

\section{Analytical Chemistry}

Aliphatic and aromatic hydrocarbons were analysed using a sample preparation method modified from UNEP. ${ }^{16}$ Oven dried $\left(50^{\circ} \mathrm{C}\right)$ sediment samples ( 25 grams) were spiked with internal standards: $\mathrm{C}_{18: 1}$ for the aliphatic hydrocarbon fraction, and 9,10-dihydroanthracene for the aromatic hydrocarbon fraction. The samples were Soxhlet extracted for $16 \mathrm{~h}$ into $100 \mathrm{~mL}$ of dichloromethane/hexane (50:50). The extracts were then concentrated down to few $\mathrm{mL}$ using rotary evaporation followed by pure nitrogen "blow down". Sulphur was removed by shaking the solution with activated copper. Clean-up and fractionation was performed by using silica/alumina (5\% deactivated) column. Elution was performed using hexane to yield the first fraction (containing the aliphatic hydrocarbons), followed by hexane/dichloromethane (70:30) to yield the second fraction (containing the aromatic hydrocarbons (PAHs)).

The hydrocarbon fractions were analysed by gas chromatography using a Hewlett Packard HP5890 series II with a flame ionisation detector (FID) (Palo Alto, CA). A SE-54 fused silica capillary column was used (HP-Ultra 2 crosslinked 5\% phenyl, 95\% methylsiloxane, $25 \mathrm{~m}$ length, $0.32 \mathrm{~mm}$ i.d., $0.17 \mu \mathrm{m}$ film thicknesses). The oven temperature was programmed from $40{ }^{\circ} \mathrm{C}$ to $60{ }^{\circ} \mathrm{C}$ at the rate of $40{ }^{\circ} \mathrm{C} \mathrm{min}^{-1}$; from $60{ }^{\circ} \mathrm{C}$ the temperature was increased at $5^{\circ} \mathrm{C} \mathrm{min}^{-1}$ to $290{ }^{\circ} \mathrm{C}$ where the temperature was held for $10 \mathrm{~min}$. Injector and detector temperatures were maintained at $280^{\circ} \mathrm{C}$ and $325^{\circ} \mathrm{C}$, respectively. Helium 
was used as a carrier gas at a flow of $1.2 \mathrm{~mL} \mathrm{~min}^{-1}$. Confirmation of peak identity was obtained for selected extracts using GC with mass spectrometric detection (GCMS) (V.G. Masslab-Fisons TRIO 1000).

Concentrations of individual aliphatic ( $n-\mathrm{C} 12$ to $n$-C 35 , pristane and phytane) and aromatic hydrocarbons (24 compounds) were quantified relative to the peak area of the respective external standards following calibration with authentic compounds and against the corresponding internal standard. The measure of total aliphatic hydrocarbons includes all resolved peaks and the area covered by the unresolved complex mixture (UCM), which is a mixture of many structurally complex isomers and homologues of branched and cyclic hydrocarbons that cannot be resolved by capillary GC columns. ${ }^{17} \mathrm{UCM}$ is quantified against the internal standards and assumes a response factor of 1 . "Total" PAH quantified using GC-FID is the sum of naphthalene, 1-methyl naphthalene, 2-methyl naphthalene, biphenyl, 2,6-dimethyl naphthalene, acenaphthylene, acenaphthene, 2,3,5-trimethyl naphthalene, fluorene, phenanthrene, anthracene, 1-methyl phenanthrene, fluoranthene, pyrene, benz(a)anthracene, chrysene, benzo(b)fluoranthene, benzo(k)fluoranthene, benzo(e) pyrene, benzo(a)pyrene, perylene, indeno(1,2,3-cd)pyrene, dibenz(a,h)anthracene and benzo(g,h,i)perylene.

Recoveries ranged from $68 \pm 6 \%$ to $106 \pm 10 \%$, and averaged $92 \%(\mathrm{n}=3)$ for aliphatic hydrocarbons and 72 $\pm 5 \%$ to $108 \pm 7 \%$, and averaged $95 \%(n=4)$ for PAHs. Detection limits (blank $+3 \mathrm{RSD})^{16}$ ranged from 0.6 to 2.1 $n g \mathrm{~g}^{-1}$ (dry wt) for $n$-alkanes and 0.8 to $13.2 \mathrm{ng} \mathrm{g}^{-1}$ (dry wt.) for individual PAHs. Appropriate blanks were analysed and, in addition, reference material IAEA-357 was analysed simultaneously. Results for all hydrocarbons quantified in the reference material were within $93 \pm 15 \%$ $(n=3)$ of the certified values.

\section{Enzyme-Linked Immunosorbent Assay (ELISA)}

Two commercially available immunoassay ELISA kits were tested: the BTEX RaPID Assay ${ }^{\circledR}$ and the carcinogenic PAH (c-PAH) RaPID Assay ${ }^{a}$ (SDI Europe, Alton, UK). RaPID Assays ${ }^{\circledR}$ are tube-based immunoassays where the polyclonal antibodies are immobilised onto paramagnetic particles. These kits are based on a competitive heterogeneous ELISA.

A simple extraction was performed prior to analysis using the SDI extraction kit for PAHs (SDI Europe, Alton, UK). ${ }^{18,19}$ Ten grams ( $10 \mathrm{~g}$ ) of sediment and $20 \mathrm{~mL}$ of $100 \%$ methanol were added to an extraction jar (with 3 stainless steel ball bearings per jar) and capped. The extraction jar was shaken vigorously for $5 \mathrm{~min}$ and allowed to settle for
$15 \mathrm{~min}$. Approximately $1 \mathrm{~mL}$ of the extract supernatant was filtered using a filtration plunger fitted with a fibre glass filter. The filtered extracts were diluted 1:10 for BTEX RaPID Assay ${ }^{\circledR}$ and 1:50-500 for c-PAH RaPID Assay ${ }^{\circledR}$ with $50 \% \mathrm{v} / \mathrm{v}$ methanol/buffered aqueous solution (containing stabilisers and preservatives) (SDI diluent). The BTEX and c-PAH RaPID Assay ${ }^{\circledR}$ were used according to the manufacturer's recommendations. Briefly, samples were analysed in triplicate together with 4 calibration standards for each RaPID Assay ${ }^{\circledR}$. Appropriate amounts of samples or standards, antibody-coated microbeads (antianalyte antibodies immobilised onto paramagnetic particles) and enzyme conjugate (analyte-horseradish peroxidase) were mixed and incubated. After washing twice with kit buffer using a magnetic rack to retain the antibodies, substrate (hydrogen peroxide) and chromogen (3,3',5,5'-tetramethylbenzidine) were added and incubated. Stop solution ( $2 \mathrm{~mol} \mathrm{~L}^{-1}$ sulphuric acid) was added and the colour produced was measured at $450 \mathrm{~nm}$ using an Optimax microplate reader (Molecular Devices, Menlo Park, CA). Sample concentrations were calculated using a log-logit standard curve and multiplying results by the appropriate dilution factors.

The RaPID Assays ${ }^{\circledR}$ were evaluated in a quantitative mode as described in the manufacture's instructions. Analytical results were calculated from a standard curve of $0,0.54,2.1$ and $18 \mathrm{mg} \mathrm{BTEX} \mathrm{L}{ }^{-1}\left(\mathrm{r}^{2}=-0.999\right.$; slope $=$ -0.532 ; interception $=-0.342$ ) for the BTEX RaPID Assays ${ }^{\circledR}$ or a standard curve of $0,0.1,1$ and $5 \mathrm{ng}$ benzo(a)pyrene $\mathrm{mL}^{-1}\left(\mathrm{r}^{2}=-0.997\right.$; slope $=-0.580$; interception $=-0.550$ ) for the c-PAH RaPID Assay ${ }^{\circledR}$. Sample concentrations were calculated by multiplying results by the appropriate dilution factor

The BTEX RaPID Assay ${ }^{\circledR}$ and c-PAH RaPID Assay ${ }^{\circledR}$ were developed using equal proportions of 6 BTEX compounds (benzene, toluene, ethyl-benzene and $\mathrm{m}$-, $\mathrm{o}$ and $p$-xylene) and benzo(a)pyrene as the hapten, respectively. Hence the different compositions within the environmental extracts render the "quantitative" measure a comparative of BTEX "equivalents" or benzo(a)pyrene "equivalents", respectively.

\section{Results and Discussion}

\section{ELISA analytical performance}

The linearity of standard calibration curves for BTEX and benzo(a)pyrene analysed by the respective ELISAs was $>0.99$ for both kits. The method detection limits (MDL), as estimated at $90 \% \mathrm{~B} / \mathrm{Bo}$ (where $\mathrm{B} / \mathrm{Bo}$ is the absorbance observed for a sample or standard divided by 
the absorbance at the zero standard) for the BTEX or c-PAH calibration dilutions, were $1.08 \mu \mathrm{g} \mathrm{g}^{-1}$ and $5.5 \mathrm{ng}$ $\mathrm{g}^{-1}$, respectively. B/Bo is the absorbance observed for a sample or standard divided by the absorbance at the zero standard. A $10 \%$ inhibition of signal was considered to be significantly different from the zero analyte concentration, and was used to estimate the sensitivity of the assay giving the method detectable limit (MDL) at $90 \% \mathrm{~B} / \mathrm{Bo}^{20}$ The $50 \% \mathrm{~B} / \mathrm{Bo}\left(\mathrm{IC}_{50}\right)$ (the concentration required to inhibit one-half of the colour produced by the negative control) was $63.6 \mu \mathrm{g} \mathrm{g}^{-1}$ and $255 \mathrm{ng} \mathrm{g}^{-1}$ for the BTEX and c-PAH RaPID Assay ${ }^{\circledR}$, respectively. The coefficient of variation $(\% \mathrm{CV})$ for repeated analyses for a single sample was 16 $\pm 8 \%(n=5)$ and $6.7 \pm 4 \%(n=5)$ for BTEX and c-PAH, respectively. These are similar to variations within conventional analytical techniques.

Inherent to the use of antibodies is a certain degree of cross-reactivity, the binding of structurally related compounds to the antibody. The degree to which a particular antibody selectively binds the analyte of choice determines its applicability. A low degree of cross-reactivity makes it suitable for single-compound assays. In contrast, a group-specific assay requires an antibody having a high degree of cross-reactivity. Thus, the selection of antibody depends on the purpose of application. Generally, an antiserum consisting of several types of antibodies (polyclonal) shows a broader spectrum of cross-reactivities than a monoclonal antibody. ${ }^{1}$ The ELISAs being tested are polyclonal and are thus suitable to detect multi-component mixtures such as hydrocarbons.

In the present study, the cross-reactivity against other PAHs and other petroleum products are described in the manufacture's instructions as the method detectable limit (MDL) and 50\% B/Bo (also available as supplementary information). However, comparisons are hindered since cross-reactivity often varies with the dose of cross-reactant due to non-parallel displacement curves (usually, but not always, with higher cross-reactivity at lower doses). In addition, the commercial assays generally describe the cross-reactivities of an individual cross-reactant at one fixed concentration and using a clean matrix, either distilled or ground water. ${ }^{20}$ This would affect comparisons with environmental samples. In spite of this, results indicate that the ELISAs will detect most aliphatic and small PAHs (BTEX RaPID Assay ${ }^{\circledR}$ ) and $\geq 4$ ring PAHs (cPAH RaPID Assay ${ }^{\circledR}$ ) (albeit with differing sensitivities) potentially affording an effective monitor for environmental hydrocarbons (aliphatics + PAHs).

The accuracy of immunoassay-based methods, as with most analytical methods, depend on the integrity of the standards used to calibrate them. The history of a standard is important since the concentration of the standards may change over time after the first use. ${ }^{2}$ Small discrepancies in concentrations (smaller than stated) have been reported for RaPID Assay ${ }^{\circledR}$ calibration standards. ${ }^{13}$ However, none of the standards supplied and used in this study appeared to contain less than the assigned concentration at first use. The best indicator of the integrity of the standards (and reagents as a whole) is the B/Bo \%. This treatment of the data effectively cancels out variations in absolute absorbance measurements resulting from inherent variability of the assay. The B/Bo \% values for a particular standard concentration should remain relatively constant and can be used as an index of quality control. ${ }^{2}$ The B/Bo \% values for all the BTEX standards used in the BTEX RaPID Assay ${ }^{\circledR}$ were $80.3 \pm 1.4 \%$ (for the $0.54 \mu \mathrm{g} \mathrm{g}^{-1}$ standard, $\mathrm{n}=3$ replicates), $62.8 \pm 0.8 \%$ (for the $2.1 \mu \mathrm{g}$ $\mathrm{g}^{-1}$ standard, $\mathrm{n}=3$ ), $42.3 \pm 1.2 \%$ (for the $18 \mu \mathrm{g}$ $\mathrm{g}^{-1}$ standard, $\mathrm{n}=3$ ). Values obtained for all the benzo(a)pyrene standards used in the c-PAH RaPID Assay ${ }^{\circledR}$ were $86.3 \pm 1.6 \%$ (for the $0.1 \mathrm{ng} \mathrm{g}^{-1}$ standard, $\mathrm{n}$ $=3$ replicates), $65.8 \pm 1.8 \%$ (for the $1.0 \mathrm{ng} \mathrm{g}^{-1}$ standard, $\mathrm{n}=3$ ), $39.0 \pm 2.1 \%$ (for the $5.0 \mathrm{ng} \mathrm{g}^{-1}$ standard, $\mathrm{n}=3$ ). These values compared well with other BTEX and c-PAH RaPID Assay kits previously used by the author. These comparison results were not described in the text.

\section{Performance of ELISAs}

\section{Sediment extraction}

An important disadvantage of the commercially available immunoassay is the associated extraction kit. The samples are mixed with $20 \mathrm{~mL}$ of methanol and shaken vigorously for at least 60s (5 minutes in present research). The samples are then left to settle, filtered and diluted with buffer solution. This procedure is, more or less, the same for all immunoassay test kits, since methanolic solutions are compatible with the assay. ${ }^{18,19}$ Knowing that even Soxhlet extraction for several hours can show incomplete extraction or have different analyte and/or matrix dependent extraction efficiencies, it is not surprising that there are differences between the results obtained with immunoassay test kits and those obtained with conventional analytical methods. ${ }^{13}$ It is suggested that lower ELISA PAH concentrations are generated because methanolic extraction cannot effectively remove all the PAH from the samples. ${ }^{3,21}$ In addition, the sediment type can also influence the efficiency of extraction, where clay type sediments have less efficient extraction of PAHs. ${ }^{2}$ 


\section{BTEX RaPID Assay ${ }^{\circledR}$ results}

A total of 24 sediment samples were analysed. Five sediment samples spiked with a mixture of $n-\mathrm{C}_{12}-\mathrm{C}_{35}(14$ to $112 \mu \mathrm{g} \mathrm{g}^{-1}$ ) and, additionally, a sediment reference material (IAEA 383) were analysed in triplicate, whilst sixteen environmental sediment samples from the Patos Lagoon estuary (southern Brazil) were analysed singly.

The concentrations of aliphatic and small aromatic hydrocarbons (expressed as BTEX "equivalents") found by the ELISA were plotted against the "total" concentrations measured by GC/FID (Figure 1). The spiked sediment extracts were differentiated from all other samples. The ELISA results for the spiked sediments gave a best-fit straight line with an $\mathrm{r}^{2}$ value of 0.94 and slope of 1.25. Although this shows good agreement between both techniques, the slope is indicative of the higher immunoreactivity of the $\Sigma n$-alkane spiked samples relative to that of BTEX standards.

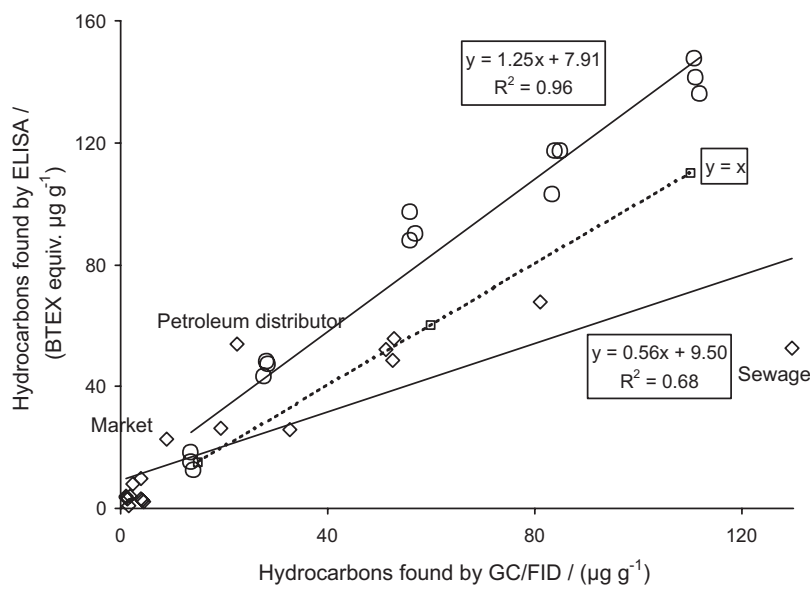

Figure 1. Plot of results from the BTEX RaPID Assay ${ }^{\circledR}$ ELISA and GC/ FID analyses of the aliphatic and small aromatic hydrocarbon compounds in extracts of $\Sigma n-\mathrm{C}_{14}-\mathrm{C}_{36}$-fortified sediment samples $(\mathrm{O})$ and environmental sediment samples $(\diamond)$ (GC results indicate the sum of alkanes, $\mathrm{UCM}$ and $\leq 3$ ring PAHs).

The results for the environmental samples also show a reasonable agreement between the techniques $\left(r^{2}=0.68\right.$, slope $=0.56)($ Figure 1$)$. In this case, the aliphatic and small aromatic hydrocarbons found by ELISA are compared with GC/FID results (which include the sum of alkanes, unresolved complex mixture and $\leq 3$ ring PAHs). The slope indicates a lower reactivity compared to that of BTEX standards. The UCM might be responsible for the lower reactivity with these ELISA antibodies, since is dominant in most of these samples $(15.5-98 \%$, with an average of $73.3 \%$ ). The sample with the highest UCM (Sewage, 98\%) is the one showing the lowest reactivity (Figure 1). Samples with less UCM $(<80 \%)$ and more $\leq 3$ ring aromatics $(>7 \%)$ show increased reactivity (e.g.
Market and Petroleum distributor, Figure 1). The analytical data for these samples can be found at Medeiros et al. ${ }^{22}$ However, if only the alkanes and $\leq 3$ ring PAHs are compared with the ELISA results, no relationship is found $\left(r^{2}=0.10\right)$, confirming that the UCM is cross-reacting with the antibodies. Indeed, this would concur with data published by Gouch and Rowland ${ }^{23}$ and Rowland et al. ${ }^{24}$ who report on the composition of the aliphatic UCM and composition and toxicity of aromatic UCM, respectively. These authors confirm that the composition of aliphatic UCM consists primarily of linear carbon chains connected at branch points, which result in "T-shaped" molecules, ${ }^{23}$ while aromatic UCM includes the presence of alkylbenzenes and C-ring mono-aromatic steroids (revealed by GC-MS mass fragmentography). These constituents are expected to react with the BTEX RaPID Assay ${ }^{\circledR}$ antibodies. The absence of a correlation when the UCM components are removed from the GC data cannot, however, discount contributions of components in the extracts which are not quantified by the selected GC analytical techniques (e.g. volatiles). Nevertheless, since the sediments were oven dried most of the volatiles should have been lost before the analyses.

The BTEX RaPID Assay ${ }^{\circledR}$ uses equivalent parts of benzene, toluene, ethyl-benzene and $m$-, $o$ - and $p$-xylene as the cross reactants set as $100 \%$. Other hydrocarbon compounds react in weaker (or much weaker) ways compared to the main targets. Again, depending on the individual hydrocarbon composition of each sediment, the response of the total petroleum hydrocarbon ELISA will differ. Consequently this test cannot be used as a quantitative method for determining the aliphatic and small aromatic hydrocarbons in sediment. The concentrations derived from the ELISA should not, therefore, be treated as absolute and accurate measurements, but rather relative comparisons between samples.

\section{PAH RaPID Assay ${ }^{\circledR}$ results}

A total of 25 sediment samples were analysed: four PAH-spiked sediment samples (18, 177, 670 and 1,650 ng $\mathrm{g}^{-1}$ ), five sediment reference materials (HS-4B, HS-5, IAEA 383, QPH16MS and QPH17MS) and sixteen environmental sediment samples (from the Patos Lagoon estuary, southern Brazil).

The concentrations (PAH "equivalents") found by the ELISA were plotted against the "total" concentrations measured by GC/MS (Figure 2). The spiked sediment extracts were differentiated from other samples. The ELISA results gave a best-fit straight line with an $\mathrm{r}^{2}$ value of 0.97 and a slope of 1.22. This indicates good agreement between the two techniques. The slope indicates higher 
immuno-reactivity of the PAH-spiked samples relative to that of benzo(a)pyrene calibration standard.

The ELISA results for the other samples also showed good agreement with the GC data $\left(r^{2}=0.87\right.$, slope $\left.=0.44\right)$ (Figure 2). In this case, the c-PAHs found by ELISA are compared with GC/MS results for $\Sigma \geq 4$ ring PAHs. The slope indicates a lower reactivity compared to that of benzo(a)pyrene calibrant. The analysed sediment samples were 0.4-0.8 times as reactive with the antibodies as benzo(a)pyrene (except for the samples Petroleum distributor (0.3 times), Mangueira (0.2 times; with only low reactivity compounds), Fertilizer industry (1.3 times; with high UCM) and Sewage (1.9 times; with high UCM)). The analytical data for these samples can be found at Medeiros et al. ${ }^{22}$ In the field samples, shifts in relative compositions of complex mixtures of PAH are apparent, which alter the ELISA response. For example, the sample Mangueira contained phenanthrene, fluoranthene and pyrene as major constituents but no five or six ring compounds were detected. These differences in response result from the fact that the antibodies were produced against benzo(a)pyrene (a 5 ring $\mathrm{PAH}$ ). Thus, the different shaped/sized PAH will react at different degrees. The correlation between immunoassay and chromatographic $\mathrm{PAH}$ results, as might be expected, was better using the sum of PAHs $\geq 4$ rings than the total PAH. Other chemical compounds not quantified using the selected chromatographic technique could also, in part, be responsible for the higher ELISA kit test values.

Several other ELISA kits, which have been described in the literature, are available to measure PAHs. Various authors have investigated the RaPID Assay ${ }^{\circledR}$ PAH-ELISA performance relative to other analytical techniques and usually report overestimation by the ELISA. Chuang et al. ${ }^{3}$ working with house dust and soil, found that the

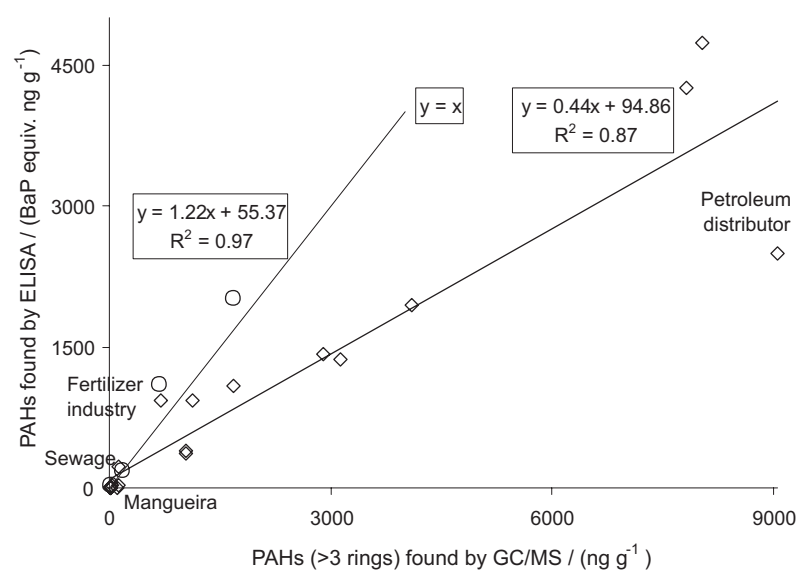

Figure 2. Plot of results from the c-PAH RaPID Assay ${ }^{\circledR}$ ELISA and GC/ FID analyses of PAH compounds ( $\geq 4$ rings) in extracts of $\Sigma 24$ PAHfortified sediments $(\bigcirc)$ and environmental sediment samples $(\diamond)$.
c-PAH RaPID Assay ${ }^{\circledR}$ ELISA measurements were 5.9 times higher than those from GC/MS. Waters et al. ${ }^{2}$ showed that a 16 component PAH mixture had 3.4-4.5 times more reactivity to the PAH RaPID Assay ${ }^{\circledR}$ ELISA antibody than phenanthrene. Kipp et al. ${ }^{13}$ working with the PAH RaPID Assay ${ }^{\circledR}$ report ELISA results 10 times higher than those obtained with HPLC. Indeed, in most cases the overestimation of the ELISA is at least one order of magnitude. ${ }^{12}$ These results concur with those obtained using an EPA protocol involving a commercial microtiter plate ELISA for PAH (EPA SW-846 Method 4035) that also give a considerable overestimation. ${ }^{25}$

Reasons for this overestimation probably relate to differences in the reactivity of compounds in the environmental extracts. Often, extracts contain many more compounds in the extract than the 15 PAHs normally quantified. These compounds most probably are isomeric or substituted analogues of the 15 quantified PAHs and, therefore, can react with the antibody leading to elevated results. $^{13}$

Although the present study reports a marginal overestimation for the "spiked" sediments, in general our results do not demonstrate the same overestimation as commonly reported. It should be noted that the kit used in our study was the carcinogenic PAH RaPID Assay ${ }^{\circledR}$ so only the work of Chuang et al. ${ }^{3}$ (who reported a 5.9 times overestimation) is strictly comparable. It is likely that discrepancies arise owing to extraction techniques. Compounds spiked into sediments are extracted more easily than compounds actually present in environmental samples. The better reactivity within the spiked samples might, therefore, be related to better recoveries. For the environmental and reference samples, the lower reactivity (slope $=0.44$, Figure 2) might relate to the extraction procedures used. Dichloromethane was used for the GC analyses, whereas methanol was used for the ELISA. In addition, Soxhlet extraction was for $16 \mathrm{~h}$ (GC samples) and that for the methanol was only 5 min (ELISA samples). Sonication would possibly improve recoveries using the methanolic extraction and provide a more effective technique to extract c-PAH from sediments, ${ }^{3}$ whilst maintaining simplicity of operation.

Analytical interferences due to the limited selectivity of antibodies (cross-reactivity) is another very important aspect to take into account when assessing ELISA performance ${ }^{26}$ Castillo et $a l .{ }^{27}$ found that many non-PAH compounds in industrial wastewater samples could be detected by the carcinogenic PAH RaPID Assay ${ }^{\circledR}$ test kit. Phthalates in particular gave high cross-reactivities. Whilst immunoassays are often used without cleaning-up the extracts, this may result in matrix interferences which 
affect performance. Values produced by immunoassay, therefore, only provide a qualitative/semi-quantitative estimate of contaminants in extracts.

The correlation experiments shown in Figure 1 and 2 clearly demonstrate the lack of accuracy of these methods for the type of samples analysed. Although the bias observed can be partially attributed to different hydrocarbon compositions present in each sample and their corresponding cross-reactivities, it is known that nonspecific interference potentially caused by the matrices can also strongly influence the response of the assay. However, no specific matrix effect addressed to evaluate the extend of these was performed, such as comparing the parallelism of standard calibration curves prepared in a "blank" sediment extract diluted several times, testing different dilution factors to the samples, or using the standard addition method. In this experiment, a standard dilution was applied only assuming as enough to reduce matrix effects, but clearly it was not enough. The application of limited clean-up techniques can often improve performance to an extent. When sediments from diverse sources are analyzed, matrix variations can differ and affect results. Within a pollution gradient with a single pollution source, however, the compositional variability is small and the performance of an immunoassay improves. ${ }^{2,28}$

\section{Conclusions}

Results from the ELISA kits tested are shown to compare well with those obtained by GC. This confirms ELISA to be a useful screening protocol with which to focus more expensive (high resolution) analytical techniques. In addition, the selected immunoassay kits are fully portable (including the spectrophotometer), affording true field deployment. Other screening techniques such as infra red and spectrofluorimetry require laboratory based measurements. The combined use of both the BTEX and carcinogenic PAH RaPID Assay ${ }^{\otimes}$ offers the capability to screen for a very wide range of hydrocarbon components to give a good measure of "total" hydrocarbons.

Our results indicate that the use of attenuation/ correction factors can improve the ELISA performance. In addition, owing to differences in cross reactivities (especially with the PAH kit), it is essential to appreciate limitations associated with compositional differences. BTEX and c-PAH RaPID Assay ${ }^{\circledR}$ ELISA cannot strictly be used as a quantitative method for determining hydrocarbons in environmental sediments, since the antibodies used bind differently to different hydrocarbons/
PAHs. The concentrations derived from the ELISA cannot, therefore, be treated as absolute and accurate measurements but rather as a rapid inexpensive and portable screening tool for environmental investigation of contamination/pollution.

\section{Supplementary Information}

This supplementary material displays some aspects of the reactivities against other hydrocarbons and petroleum products. This material is available free of charge via the Internet at http://jbcs.sbq.org.br, as PDF file.

\section{Acknowledgments}

G. Fillmann was sponsored by CAPES (Ministry of Education-Brazil) (BEX1536/96-6), WWF-Brazil/USAID (CSR-151-00) and CNPq (PQ 303218/2003-7). This research was part of the Rapid Assessment of Marine Pollution (RAMP) programme funded by a DFID-UK (Department for International Development) grant to M.H. Depledge and J.W. Readman.

\section{References}

1. Meulenberg, E. P.; Mulder, W. H.; Stoks, P. G.; Environ. Sci. Technol. 1995, 29, 553.

2. Waters, L. C.; Palausky, A.; Counts, R. W.; Jenkins, R. A.; Field Anal. Chem. Technol. 1997, 1, 227.

3. Chuang, J. C.; Pollard, M. A.; Chou, Y. L.; Menton, R. G.; Wilson, N. K.; Sci. Total Environ. 1998, 224, 189.

4. Kramer, P. M.; Anal. Chim. Acta 1998, 376, 3.

5. Kim, I. S.; Ritchie, L.; Setford, S.; Taylor, J.; Allen, M.; Wilson, G.; Heywood, R.; Pahlavanpour, B.; Saini, S.; Anal. Chim. Acta 2001, 450, 13.

6. Fillmann, G.; Galloway, T. S.; Sanger, R. C.; Depledge, M. H.; Readman, J. W.; Anal. Chim. Acta 2002, 461, 75.

7. Fritcher, D. L.; Mazet, J. A. K.; Ziccardi, M. H.; Gardner, I. A.; Mar. Pollut. Bull. 2002, 44, 388.

8. Chuang, J. C.; Van Emon, J. M.; Chou, Y. L.; Junod, N.; Finegold, J. K.; Wilson, N. K.; Anal. Chim. Acta 2003, 486, 31.

9. Price, R. G.; Baranowska, I.; Griffith, H. M. T.; Abuknesha, R. A.; Barchanska, H.; Biomarkers 2006, 11, 291.

10. Wang, S.; Yu, C. D.; Zhang, Y.; Wang, J. P.; Duan, Z. J.; Zhang, J. K.; J. Environ. Sci. Health. B 2006, 41, 693.

11. Aga, D. S.; Thurman, E. M.; ACS Symposium Series 1997, 657, 1.

12. Barceló, D.; Oubina, A.; Salau, J. S.; Perez, S.; Anal. Chim. Acta 1998, 376, 49.

13. Kipp, S.; Peyrer, H.; Kleibohmer, W.; Talanta 1998, 46, 385. 
14. Galloway, T. S.; Sanger, R. C.; Fillmann, G.; Readman, J. W.; Smith, K. L.; Ford, T. E.; Depledge, M. H.; Environ. Sci. Technol. 2002, 36, 2213.

15. Oubina, A.; Gascon, J.; Ferrer, I.; Barceló, D.; Environ. Sci. Technol. 1996, 30, 509.

16. UNEP/IOC/IAEA, Reference methods for marine pollution studies No 20, Monaco, 1992, 75p.

17. Bouloubassi, I.; Saliot, A.; Oceanol. Acta 1993, 16, 145.

18. Hottenstein, C. S.; Jourdan, S. W.; Hayes, M. C.; Rubio, F. M.; Herzog, D. P.; Lawruk, T. S.; Environ. Sci. Technol. 1995, 29, 2754 .

19. Lawruk, T. S.; Lachman, C. E.; Jourdan, S. W.; Fleeker, J. R.; Hayes, M. C.; Herzog, D. P.; Rubio, F. M.; Environ. Sci. Technol. 1996, 30, 695 .

20. Oubina, A.; Gascon, J.; Barceló, D.; Environ. Sci. Technol. 1996, $30,513$.

21. Johnson, J. C.; van Emon, J. M.; Clarke, A. N.; Wamsley, B. N.; Anal. Chim. Acta 2001, 428, 191.
22. Medeiros, P. M.; Bicego, M. C.; Castelao, R. M.; Del Rosso, C.; Fillmann, G.; Zamboni, A. J.; Environ. Int. 2005, 31, 77.

23. Gough, M. A.; Rowland, S. J.; Nature 1990, 344, 648.

24. Rowland, S.; Donkin, P.; Smith, E.; Wraige, E.; Environ. Sci. Technol. 2001, 35, 2640.

25. USEPA; Test methods for evaluation solid waste: Physical/ chemical methods, Integrated method (SW-846), Environmental Protection Agency: Springfield, USA, 1997.

26. Oubina, A.; Gascon, J.; Barceló, D.; Anal. Chim. Acta 1997, $347,121$.

27. Castillo, M.; Oubina, A.; Barceló, D.; Environ. Sci. Technol. 1998, 32, 2180.

28. Gascon, J.; Martinez, E.; Barceló, D.; Anal. Chim. Acta 1995, $311,357$.

Received: October 10, 2006

Web Release Date: July 11, 2007

FAPESP helped in meeting the publication costs of this article. 


\title{
Validation of Immunoassay Methods to Determine Hydrocarbon Contamination in Estuarine Sediments
}

\author{
Gilberto Fillmann, ${ }^{*, a}$ Márcia C. Bicego, ${ }^{b}$ Ademilson Zamboni, ${ }^{a}$ Tim W. Fileman, ${ }^{d}$ \\ Michael H. Depledge and James W. Readman ${ }^{d}$ \\ ${ }^{a}$ Fundação Universidade Federal do Rio Grande, Departamento de Oceanografia, CP 474, \\ 96201-900 Rio Grande-RS, Brazil \\ ${ }^{b}$ Universidade de São Paulo, Instituto Oceanográfico, 05508-900 São Paulo-SP, Brazil \\ ${ }^{c}$ Plymouth Environmental Research Centre, University of Plymouth, Drake Circus, Plymouth, PLA 8AA, UK \\ ${ }^{d}$ Plymouth Marine Laboratory, Prospect Place, West Hoe, Plymouth, PL1 3DH, UK
}

Table S1. Cross-reactivities against other hydrocarbons and petroleum products in the BTEX RaPID Assay® (data provided in the RaPID Assay® SDI Product Information sheet)

\begin{tabular}{lcc}
\hline Compound & $\mathrm{MDL}^{*} /\left(\mu \mathrm{g} \mathrm{g}^{-1}\right)$ & $50 \%{\mathrm{~B} / \mathrm{Bo}^{*} /\left(\mu \mathrm{g} \mathrm{g}^{-1}\right)}^{-1}$ \\
\hline$m$-Xylene & 0.6 & 36 \\
$p$-Xylene & 2.6 & 62 \\
$o$-Xylene & 4.4 & 94 \\
Ethylbenzene & 4.8 & 156 \\
Toluene & 8.8 & 148 \\
Benzene & 11.8 & 1,000 \\
Naphthalene & 0.6 & 11.8 \\
Anthracene & 1.2 & 560 \\
Styrene & 1.4 & 52 \\
Hexachlorobenzene & 1.6 & $\mathrm{NR}$ \\
Phenanthrene & 1.6 & 32 \\
Acenaphthene & 3.4 & 124 \\
$n$-Octane & 68 & $\mathrm{NR}$ \\
$n$-Nonane & 88 & $\mathrm{NR}$ \\
$n$-Heptane & 126 & $\mathrm{NR}$ \\
$n$-Decane & 270 & $\mathrm{NR}$ \\
Methylene Chloride & $\mathrm{NR}$ & $\mathrm{NR}$ \\
Trichloroethylene & $\mathrm{NR}$ & $\mathrm{NR}$ \\
Gasoline & 8.6 & 842 \\
Diesel & 25.8 & 324 \\
Kerosene & 30 & 480 \\
Jet-A Fuel & 54 & 670 \\
\hline
\end{tabular}

$\mathrm{NR}$ - non reactive up to $1,000 \mu \mathrm{g} \mathrm{g}^{-1} ;{ }^{*}$ based on a 20 -fold dilution of the sediment extract.
Table S2. Cross-reactivities against other PAHs and petroleum products in the c-PAH RaPID Assay ${ }^{\circledR}$ (data provided in the RaPID Assay ${ }^{\circledR}$ SDI Product Information sheet)

\begin{tabular}{lcc}
\hline Compound & $\mathrm{MDL}^{*} /\left(\mathrm{ng} \mathrm{g}^{-1}\right)$ & $50 \%{\mathrm{~B} / \mathrm{Bo}^{*} /\left(\mathrm{ng} \mathrm{g}^{-1}\right)}^{-1}$ \\
\hline Benzo(a)pyrene & 4.0 & 160 \\
Benz(a)anthracene & 1.0 & 48 \\
Benzo(k)fluoranthene & 1.0 & 63 \\
Chrysene & 2.0 & 69 \\
Benzo(b)fluoranthene & 2.0 & 130 \\
Indeno(1,2,3-c,d)pyrene & 1.0 & 203 \\
Dibenz(a,h)anthracene & 7.0 & 241 \\
Anthracene & 22 & 2,050 \\
Phenanthrene & 135 & 6,720 \\
Fluoranthene & 100 & 6,850 \\
Benzo(g,h,i)perylene & 15 & $>10,000$ \\
Pyrene & 100 & 23,300 \\
Fluorene & 1,850 & 34,200 \\
Naphthalene & 18,800 & $\mathrm{NR}$ \\
Acenaphthylene & 7,400 & $\mathrm{NR}$ \\
Acenaphthalene & $\mathrm{NR}$ & $\mathrm{NR}$ \\
Creosote & 62 & 838 \\
Fuel Oil \#4 & 1,260 & 30,400 \\
Fuel Oil \#5 & 1,000 & 20,700 \\
Heating Fuel & 1,000 & 65,300 \\
Diesel Fuel & 12,000 & $\mathrm{NR}$ \\
Gasoline & 10,000 & $\mathrm{NR}$ \\
Kerosene & $\mathrm{NR}$ & $\mathrm{NR}$ \\
Jet A Fuel & $\mathrm{NR}$ & $\mathrm{NR}$ \\
\hline
\end{tabular}

$\mathrm{NR}$ - non reactive up to $50,000 \mathrm{ng} \mathrm{g}^{-1}$; * based on a 100 -fold dilution of the sediment extract.

*e-mail: gilberto@pq.cnpq.br 